Instructions for authors, subscriptions and further details:

http://ijep.hipatiapress.com

\title{
Using Metaphors to Know the Conceptions about the Teaching Profession in Initial Teacher Education
}

Zoe Martínez-de-la-Hidalga \& Lourdes Villardón-Gallego ${ }^{1}$

1) University of Deusto, Spain

Date of publication: June $24^{\text {th }}, 2017$

Edition period: June 2017 - October 2017

To cite this article: Martínez-de-la-Hidalga, Z., \& Villardón-Gallego, L. (2017). Using metaphors to know the conceptions about the teaching profession in initial teacher education. International Journal of Educational Psychology, 6(2), 183-208. doi: 10.17583/ijep.2017.2602

To link this article: http://dx.doi.org/10.17583/ijep.2017.2602

\section{PLEASE SCROLL DOWN FOR ARTICLE}

The terms and conditions of use are related to the Open Journal System and to Creative Commons Attribution License (CC-BY). 


\section{Using Metaphors to Know the Conceptions about the Teaching Profession in Initial Teacher Education}

Zoe Martínez-de-la-Hidalga, Lourdes Villardón-Gallego

University of Deusto

\section{Abstract}

The Conceptions about the teaching profession affect professional performance, and metaphors are a tool to identify them. In this qualitative study metaphors are used to gain insight into conceptions held by pre-service teachers, and their development during Initial Teacher Training in the Bachelor's Degree in Primary Education. A total of 247 students participated in this cross-sectional study; 145 were first-year students, and 102 were fourth-year students. Participants were requested to submit a metaphor following the open-ended formula: "the teacher is like.... because..." In order to categorize their answers, we used an inductive method and calculated frequencies and percentages. Metaphors were grouped according to the following categories: a) Main Character; b) Support; c) Family; d) Social Agent e) Teaching; f) Importance. The most frequent category was Support, followed by Teaching and Family. First-year pre-service teachers referred to Family, Teaching and the Main Character role of teachers more often than students in their fourth year, whereas the latter allude more often than the former to the teachers' role as providers of Support and as Social Agents. There is evidence of moving from a transmissive to a constructivist and transformative educational perspective, but there is no indication of any evolution towards a socioconstructivist outlook.

Keywords: professional identity, initial teacher education, metaphor, primary education, qualitative research. 


\section{Utilizando la Metáfora para Conocer las Concepciones sobre la Profesión Docente en la Formación Inicial del Profesorado}

Zoe Martínez-de-la-Hidalga, Lourdes Villardón-Gallego

University of Deusto

\section{Resumen}

Las concepciones sobre la profesión son importantes porque afectan al desempeño. La metáfora es una herramienta para identificarlas. En esta investigación se utiliza la metáfora para conocer las concepciones de los estudiantes de profesorado y su evolución a lo largo de la formación inicial en el Grado de Educación Primaria. Es un estudio transversal en el que han participado un total de 247 estudiantes, 145 de primer curso y 102 de cuarto. Se les preguntó la metáfora de forma abierta: "el profesor es como ... porque ...”. Para categorizar las respuestas se siguió el método inductivo. Una vez establecidas éstas, se calcularon frecuencias y porcentajes. Las metáforas se agrupan en las siguientes categorías: a) protagonista; b) apoyo; c) familia, d) agente social; e) enseñanza y f) importancia. La más frecuente es el Apoyo, seguida de la Enseñanza y la Familia. Los estudiantes de primer curso hacen más referencia a la Familia, a la Enseñanza y al papel Protagonista del profesor que los de cuarto, y éstos hacen más referencia al Apoyo y al profesor como Agente Social que los de primero. Se percibe evolución de una perspectiva transmisiva de la enseñanza a una perspectiva constructivista $y$ transformadora, pero no a una perspectiva socioconstructivista.

Palabras clave: identidad profesional, formación inicial de profesorado, metáfora, educación primaria, investigación cualitati 
onceptions of teaching are a key part of professional identity. In this case, and based on the definition provided by Sexton (2008), professional identity can be defined as the subjective meaning of being a teacher in a specific context. The conceptions regarding the teaching profession can affect professional performance (McGrath, 2006; Mahlios, Massengill-Shaw and Barry, 2010); consequently, their impact on the quality of education and on teacher training makes them an important subject of study (Impedovo, 2016). Furthermore, beliefs regarding the teaching profession, which start coalescing during the early stages of students' lives, shape both what is learned and how it is learned during initial teacher education; therefore, these beliefs must be identified (Farrell, 2006), most notably because one of the objectives of initial teacher education is the development of a system of reasoned beliefs that can substitute the unquestioned, unreasoned conceptions (Seferoglu, Korkmazgil and Ölcü, 2009) stemming in part from pre-service teachers' own experience as students (Boyd, 2014).

Conceptions are not easy to measure or identify, because they are mostly implicit (Wegner and Nückes, 2015). However, metaphors are a valid resource to gather information on conceptions, as people use metaphors to provide structure to abstract concepts such as justice and spirituality, among others (Landau, Meier and Keefer, 2010), which makes them an important cognitive tool and an essential vehicle for communication (Nikitina and Furuoka, 2008). Metaphors act as lenses through which we perceive the world around us (Wegner and Nückes, 2015). Complex concepts can become simplified through metaphors, which helps understand both world and experience (Tait-McCutcheon and Drake, 2016). In essence, metaphors are windows that provide insight onto the way in which people conceptualize the world and reality (Lakoff and Johnson, 1980).

Wegner and Nückles (2015) remark that not all research interprets in the same way the cognitive theory on metaphors proposed by Lakoff and Johnson (1980). The "strong version" regards metaphors as constituting the conception itself, whereas the "weak version" considers metaphors to help express or identify an underlying conception based on shared features. Thus, metaphors are the source -usually something more specific and familiar- 
186 Martínez-de-la-Hidalga \& Villardón-Gallego-Using Teaching Metaphors

that facilitates an understanding of the professional image, more abstract and harder to communicate.

It is interesting to interpret metaphors bearing in mind the distinction, as devised by Schön (1979) (cited by Vadeboncoeur and Torres, 2003), between generative or deep metaphors and superficial metaphors. The former are assumptions, of which we are often not fully aware, that sometimes limit our perceptions and our search for solutions. The latter, more explicit, provide clues that reveal the former; a new superficial metaphor can generate new perceptions and explanations. In the subject at hand, deep metaphors help understand the underlying discourse as teachers; the superficial ones, in turn, provide information regarding the process of building and reshaping the roles of teachers and teaching itself.

Many studies on education have used metaphors as tools to gather information. Most of them have focused on the conceptions of teachers or pre-service teachers regarding teaching and learning (Wegner and Nückles, 2015), as well as professional practice and the profession (Kramsch, 2003; Leavy, McSorley and Boté, 2007; Kasoutas and Malamitsa, 2009; Saban, Kocbeker and Saban, 2006). Others have focused on specific aspects of professional practice, such as educational supervision (Akan, Yalçin and Yildirim, 2013) or educational institutions (Konakli and Gogus, 2013). Additionally, some studies have used metaphors to promote and study the evolution of conceptions related to a variety of aspects of professional performance throughout training in order to determine the efficacy of a specific training approach (Perry and Cooper, 2001; Akar and Yildirin, 2009; Farrell, 2006).

Emmerson and Mansvelt (2014) reviewed the classifications of metaphors related to teaching and learning. The simplest is Sfard's (1998), who distinguishes only two: the category for acquisition, in which learning is described as the individual acquisition of knowledge, and the metaphor of participation, in which learning is conceived as participation in a learning community. Martínez, Sauleda and Huber (2001), in turn, describe three categories for metaphors: the category for metaphors that support a behavioral approach (representative of teaching-learning, in which students adopt a passive role); the one for metaphors that support a cognitive/constructivist approach, in which students adopt an active role in 
the building of knowledge; and metaphors that support the sociohistorical perspective of social learning, which regards learning as happening in a community of practice, through dialogue and collaboration, rather than individually.

Pinnegar, Mangelson, Reed and Groves (2011), analyzed the metaphors of female applicants wishing to pursue teacher education in college, and they identified 12 roles of teachers: celebrity, creator, expert, friend, leader, learner, mentor, nurturer, performer, redeemer, scaffolder, and self-sacrificer.

There are no studies in our geographical area that use metaphors to study the professional conceptions of pre-service teachers and their evolution throughout training. Therefore, the goal of this study is to get to know, by use of metaphors, the conception of profession held by pre-service teachers in Bizkaia. Additionally, this study will analyze the differences that might exist between the ideas pre-service teachers have at the beginning of their training $\left(1^{\text {st }}\right.$ year $)$ and their ideas at the end of their initial teacher training $\left(4^{\text {th }}\right.$ year), in order to determine how training affects the development of the professional image.

\section{Method}

\section{Participants}

The population comprises first-year students and final-year students in the Bachelor's Degree in Primary Education at the Faculty of Psychology and Education of the University of Deusto (UD), as well as the UD -affiliated Begoñako Andra Mari (BAM).

The total sample of volunteering pre-service teachers is composed of 247 undergraduate students, of which 144 are women and 103 are men. The average age of the students taking part in the study was 20.6 years of age. The students in their first year of university had initiated their studies in the 2013-2014 school year, whereas the students in their fourth year finished their studies in the 2012-2013 school year.

The sub-sample of first-year students in the Bachelor's Degree in Primary Education is composed of 145 students (Table 1). 
188 Martínez-de-la-Hidalga \& Villardón-Gallego-Using

Teaching Metaphors

Table 1

Sub-sample of first-year students, according to university, concentration and gender.

\begin{tabular}{llll}
\hline \multirow{2}{*}{ University } & \multirow{2}{*}{ Concentration } & Gender & \\
& & Female & Male \\
\cline { 2 - 4 } & Physical Education & 7 & 43 \\
BAM $^{1}$ & Foreign Languages & 10 & 6 \\
& Curriculum & 17 & 8 \\
\cline { 2 - 4 } UD $^{2}$ & Foreign Languages & 14 & 8 \\
& Special Education & 27 & 5 \\
\hline
\end{tabular}

${ }^{1}$ BAM: Begoñako Andra Mari

${ }^{2}$ UD: University of Deusto

Of the 145 first-year undergraduate students that volunteered for the study, 54 belonged to the University of Deusto (37.24\%) and 91 belonged to the Begoñako Andra Mari, the affiliated institution (62.76\%); 75 were women $(51.72 \%)$ and 70 were men $(48.28 \%)$, which accurately reflects the real demographics of first-year students in the Bachelor's Degree in Primary Education. The average age of the participants was 18.5 years of age.

Regarding the concentrations pursued by the participants, 50 students had chosen Physical Education (34.48\%); 25 had elected a concentration on Curriculum (17.24\%); 38 students had opted for Foreign Languages (26.21\%); and, finally, 32 students had selected Special Education (22.07\%).

The sub-sample of $4^{\text {th }}$ year students in the Bachelor's Degree in Primary Education, in turn, comprises 102 students (Table 2), of which 49 belonged to the University of Deusto (48.03\%), whereas 53 belonged to Begoñako Andra Mari (51.97\%). The participants were 69 women (67.65\%) and 33 men (33.35\%). Their average age was 22.7 years old. 
Table 2

Sub-sample of fourth-year students, according to university, concentration and gender.

\begin{tabular}{llll}
\hline \multirow{2}{*}{ University } & \multirow{2}{*}{ Concentration } & Gender & \\
\cline { 2 - 4 } & & Female & Male \\
\cline { 2 - 4 } BAM $^{1}$ & Physical Education & 6 & 14 \\
& Foreign Languages & 5 & 4 \\
\multirow{2}{*}{$\mathrm{UD}^{2}$} & Curriculum & 17 & 7 \\
\cline { 2 - 4 } & Foreign Languages & 15 & 3 \\
\hline
\end{tabular}

${ }^{1}$ BAM: Begoñako Andra Mari

${ }^{2}$ UD: University of Deusto

The $4^{\text {th }}$ year students were pursuing the following concentrations: 20 students had opted for Physical Education (19.61\%); 24 students had chosen the concentration on Curriculum (23.53\%); 27 students pursued Foreign Languages (26.47\%); and 31 students had selected to Special Education $(30.39 \%)$.

\section{Instruments}

Metaphors were used in an open-ended on-line interview on the perception of the teaching profession. This study assumes the "weak version" (Wegner and Nückes, 2015) of the cognitive theory on metaphors (Lakoff and Johnson, 1980), which considers metaphors to be the means through which conceptions are expressed, by way of a comparative process that identifies certain similarities between the two (metaphor and conception). Consequently, when providing metaphors, participants are asked to also provide explanations. The question was formulated as follows: "Choose one metaphor that describes the figure of 'teacher' and explain why you have chosen it".

\section{Procedure}

Upon garnering the approval to the research project from the ethics committee at the university, the managers from both institutions were contacted in order to explain the objectives of the study and request their collaboration. Subsequently, pre-service teachers were provided on-site 
190 Martínez-de-la-Hidalga \& Villardón-Gallego-Using Teaching Metaphors

information regarding the study and its volunteer-based, anonymous nature. Those who decided to participate then completed the on-line interview.

First year students completed the questionnaire at the beginning of the school year, in September 2013. Fourth year students, in turn, completed the questionnaire when they had finished their training, in May 2013. Later, the ethical committee of the university granted its approval to the research project.

\section{Data analysis}

The principles of grounded theory (Glaser and Strauss, 1967; Trinidad, Carrero and Soriano, 2006) were applied to the analysis of answers; consequently, an inductive methodology was used, which established categories after the fact, according to the content of said answers. This analytic method allows the theory to emerge from the information gathered. ATLAS.ti 7.0 software was used to analyze the contents. After categorizing the answers, frequencies and percentages were calculated in each category for each cohort.

\section{Results}

The metaphors used by students of the Bachelor's Degree in Primary Education to define teachers can be divided into six categories related to the teaching profession. These ideas on teachers are present both in first-year students (marked here with a lowercase "a") and in fourth-year students (marked with an uppercase "A"), although percentages differ.

The metaphors contributed by the pre-service teachers can be arranged in the following categories: a) teachers as main characters; b) teachers as support; c) teachers as family; d) teachers as social agents; e) role of teaching; and, finally, e) importance of the profession.

In the total sample, Support $(24,3 \%)$ and Family $(20,6 \%)$ by themselves, already represent the conceptions of nearly half the students, who think of teachers as figures that accompany and support people in their development; and nearly one-fourth of participants $(21,9 \%)$ emphasize Teaching as the main role for teachers. Importance of the profession is alluded to by $15,8 \%$, 
while $9,3 \%$ highlight the importance of teachers in students' education. Finally, 6,1\% considers them to be Social agents.

Table 3 features the frequencies and percentages obtained in each category of answers by participants in their first year and their fourth year of the Bachelor's Degree in Primary Education.

Table 3

Frequencies and percentages of answers in each category in $1^{\text {st }}$ and $4^{\text {th }}$ years

\begin{tabular}{lcccccc}
\hline Categories & \multicolumn{2}{c}{$1^{\text {st }}$} & \multicolumn{2}{c}{$4^{\text {th }}$} & \multicolumn{2}{c}{ Total } \\
& $\mathrm{N}$ & $\%$ & $\mathrm{~N}$ & $\%$ & $\mathrm{~N}$ & $\%$ \\
\cline { 2 - 7 } Social Agent & 5 & 3.5 & 10 & 9.8 & 15 & 6.1 \\
Support & 21 & 14.5 & 39 & 38.2 & 60 & 24.3 \\
Main Character & 14 & 9.7 & 9 & 8.8 & 23 & 9.3 \\
Family & 44 & 30.3 & 7 & 6.9 & 51 & 20.6 \\
Teaching & 35 & 24.1 & 19 & 18.6 & 54 & 21.9 \\
Importance & 21 & 14.5 & 18 & 17.7 & 39 & 15.8 \\
Unspecified & 5 & 3.4 & 0 & 0 & 5 & 2.0 \\
\hline
\end{tabular}

According to the data, the conception of teachers as SUPPORT is much more present at the end of teacher education (38.2\%) than it is at the beginning $(14.5 \%)$, which shows that throughout the Bachelor's Degree students become more aware of the importance of this role in the teaching profession.

In the Support category, students have submitted metaphors that underscore the role of the teacher as Guide that bears in mind students' realities, interests and differences. Hence, teachers are seen as "guides that must help students become aware of what they really like and are good at" (a94), "the key for students to be able to open different doors" (A40).

Many students consider the ultimate goal of education to be the transformation of students into autonomous people. The following image reflects that idea: "the branch that holds a worm, that, when ready to fly on 
192 Martínez-de-la-Hidalga \& Villardón-Gallego-Using Teaching Metaphors

its own, transformed into a butterfly, lets go of it and follows its own path" (A73).

Other students have stressed the need for education to unveil the full potential of people. To that effect, teachers must perform their duties with care and dedication, tending and paying attention to their students. Different objects were used to portray this idea, such as "plant fertilizer; a complement that makes plants grow stronger and more secure" (A51); "salt flakes on a Tbone steak, that bring out the best in it" (A64), as well as jobs as "farmer" or "gardener" who must tend to the plants so that they grow and shine in all their glory.

These types of jobs make it necessary to determine the different types of plants to tend, as they have different needs, which refers to diversity in students and their different needs: "the farmer who grows his vegetables: lettuce, tomatoes, carrots, leeks, pumpkins... they are not all the same, so he is not going to tend to all of them in the same way. He will also be alert, watching whether everything is growing correctly, ready at all times to act if necessary" (a8).

Some participants consider teachers to be a resource on which to lean in their personal and academic development. The analogies used to convey this idea are "a walking stick" or "an outstretched hand".

Some metaphors reflect a conception of teaching in which the teacher is the MAIN CHARACTER. There are two levels in this category. One level places teachers at the center of the training, development and fate of students, with metaphors linked to artisanal jobs of having to shape amorphous or raw materials, in reference to students, with metaphors such as "jeweler polishing a rough diamond" (a35), "hammer shaping red-hot iron" (A7), or "baker kneading the dough" (A55).

On a somewhat lower level of prominence but still being ascribed a determining role in the lives of students, there are metaphors in which teachers define students' path as the only available option: "train engineer who has to drive all the students (the wagons) to their final destination" (A48); "the Pied Piper charming the animals with his music so that they will bend to his will..." (A45); or "a boat in the river, taking the students to the sea, which is knowledge" (a7). 


\section{IJEP - International Journal of Educational Psychology, 6(2) 193}

The TEACHING category groups the metaphors referencing the teachinglearning process as the defining role of the teachers' professional performance. This professional conception is more frequent in first-year students $(24.1 \%)$ than in final-year students (18.6\%), which means that there are other roles for teachers, such as support and guidance, that become more prominent throughout their training.

This group of metaphors encompasses different conceptions of teachers as sources of knowledge, as role models or as teaching professionals.

In this category, most of the answers (11\% for first-year answers and $11.8 \%$ for final-year answers) refer to teachers as source of knowledge, people who teach and convey everything they know. Metaphors reflecting this conception describe teachers as "great library", "hard disk drive", "open book", "computer", "encyclopedia", "sage" or "open dictionary".

Besides being a source of knowledge, teachers are also seen as role models or references from which students learn. Some metaphors reflecting this idea of teachers as "models" are taken from natural phenomena that provide "a light that guides you in the development process" (A53, a111), such as "the North star" (a107), "the leading wake of a comet crossing the summer skies, which illuminates your path in the darkest hours of the night" (a116) or "the sun" (A8). Other images that reflect this idea of teachers are "the lighthouse that guides the sailors to a safe harbor" (A6) or "a movie, project it and then people will take what they want" (A71).

This category also encompasses answers referencing teachers as professionals that teach not only contents, but also other types of knowledge, such as values and attitudes: "an open book but with the ability to teach how to develop other things, such as abilities, that books don't teach" (A11).

There were references to FAMILY figures or a close person in the metaphors of $30 \%$ of first-year students, whereas only $6.9 \%$ of the last-year students mentioned this aspect. Students undoubtedly highlight the importance of the affective dimension in education, but, as they undergo their teacher training, they become more aware of the need to acquire technical skills in order to become good teachers.

In the metaphors included in this category we can also find outlines of the familial educational model, with allusions to support and education, protection, discipline or commitment. 
194 Martínez-de-la-Hidalga \& Villardón-Gallego-Using Teaching Metaphors

Along these lines, some metaphors allude to teachers as family members who not only teach, but also educate and support during students' development: "someone you can lean on, like your mother" (a17); "teachers are like family, because they're there in the good times and the bad, and they help us in everything, in addition to teaching us the necessary education" (a36).

Students are aware of the affection teachers inspire in students: "teachers are like pearls, because you are always very fond of your teacher when you're a child" (a141); "a beloved person, like a mother" (a53).

Other answers link teachers to family figures who prepare for maturity: "a lion that has to teach its cubs how to survive on their own in nature and for that it shares its wisdom to face the diverse problems that could arise in their lives" (a42); "the animal that teaches its child to walk and defend against adversity" (A77).

Additionally, some metaphors associate teachers with family, underscoring discipline and order as educational models; in this respect, teachers are shown to be authoritative, although capable of affection: "teachers have an authority similar to that of mothers, because students must obey and follow the rules established by the teacher" (a102); "it's like the alpha animal in a band of gorillas" (A9); "a mixture between father and big brother, because they help you when you need it the most, but there's also that distance and respect of someone who teaches you what to do and know, as well as admiration" (a61).

Lastly, in this category, some metaphors make reference to teachers' selflessness: "it's like an Non Governmental Organization" (A37); "it's like mothers, they give a lot and receive very little" (A75); "it's like a sponge... that wrings itself so it can give others its best" (a91).

Several of the metaphors used by students refer to teachers as SOCIAL AGENTS. They portray teachers as scaffolding on which social structure leans, and as builders of society; they also mention the fact that teaching performance is affected by external factors. This type of answer is more prevalent among last-year students (9.8\%) than among first-year students (3.5\%); these results may indicate that throughout training students develop their social conscience and become more aware of teachers' social repercussion. 


\section{IJEP - International Journal of Educational Psychology, 6(2) 195}

Similes that reflect the idea of teachers as scaffolding on which society leans include "the skeleton of the society of tomorrow" (A18); "teachers are to society like foundations to a building" (A89); and "a pillar" (a28).

The images used to convey the conception of teachers as builders of society usually include design-related, technical jobs, geared towards providing solutions to diverse situations and needs: "engineers of future subjects" (a1); "architects of society; they must balance and calculate a building, which is, in this case, society" (a4).

Some students go even further and, through their metaphors, propound the idea that teachers must not confine themselves to providing a scaffolding for society, but must also contribute to its improvement. "A tree, that keeps its roots in the ground, keeping hold of the reality chanced on it, and striving to achieve daily goals. But the treetop looks to the skies, it has to dream up how it wants to change things so that they become better" (A49).

Some fourth-year students $(n=7)$ have become aware of the need to take into consideration the context of professional performance; family environment, school, and the sociopolitical situation, are, after all, some of the elements that have either a positive or a negative influence on performance: "an elephant, who is king of the savannah, but without help from the herd (families, social environment) will most probably have trouble going on or will be "eaten"' (A5); "a chameleon that has to change colors continually, adapting to circumstances" (A43); "teachers are like design and décor, houses have common features such as power sockets, kitchen, bathroom, bed, electricity and also rules determined by laws, but ultimately we have to decorate and build taking into account the context, and the characteristics and needs of the person who is going to live in the house" (A88); "a spring that shares its very pure water among the various small wells, that will gradually become full with it and also with rainwater, in the same way that children are educated by teachers and parents and other figures; teachers are a great source of water for the children but not the only one" (a145).

Perhaps unsurprisingly, given the roles students ascribe to teachers in the education of the people of the future -as main characters, providers of support, teachers, and educators-, many metaphors reflect the IMPORTANCE of the profession (15.8\%). 
196 Martínez-de-la-Hidalga \& Villardón-Gallego-Using Teaching Metaphors

This importance shows different gradations; some consider it essential in the education of children, with similes such as "the wings of a bird; without them, the bird cannot fly; without the teacher, the child would have no wings to fly towards the future as a free bird" (a12); "like water, a basic necessity for life" (a27); "water and sun for a flower" (a26).

Some answers indicate that teachers provide the foundation for the development of people, because it provides the basis for it through education: "it's the Beginning" (a25); "the roots of a tree that grows until it becomes a tall tree that reaches far, like many children end up becoming great doctors... with the help of teachers (roots)" (a31); "the foundation when building a house, because they teach you things you will use your whole life, essential to communicate with society" (a33); "if the foundations of a house are not well built, you will never be able to build a good house, it will be slanted, it will have issues... teachers are the same thing, they provide the basis for everything" (A34); "a pillar, because anyone who invents something revolutionary or discovers the cure for some illness first started with learning" (a28); "the legs of a table, without a good educational basis, there can be no lofty goals" (a29).

Recognition of teachers' social responsibility, and the tasks and roles to perform, leads some participants to use metaphors that reflect the complexity of the job, even using fictional depictions: "a superhero" (a126); "a wizard... they have powers and strength for everything, or at least they should" (A10); "it's like an all-in-one, they must know how to do everything; be doctors, journalists, communicators, nurses, psychologists, artists, gymnasts, musicians, engineers, etc.; often we have to heal students, help families, create artworks, paint, play instruments, sing..." (A93).

Finally, their impact on students and society makes continuous improvement a necessity, as described in the metaphor of a fourth-year student: "the mountaineer always wants to climb higher" (A21).

\section{Discussion and Conclusions}

This study has used metaphors to get to know the professional conception of initial teacher education students and its evolution trough initial teacher training. 


\section{IJEP - International Journal of Educational Psychology, 6(2) 197}

The metaphors advanced by students to describe teachers have been analyzed and, subsequently, six categories have been established, sorted according to prevalence: Support, Teaching, Family, Importance, Main Character and Social Agent.

Those six categories and their corresponding sub-categories encompass nearly all the roles of teachers as identified by Pinnegar, Mangelson, Reed and Groves (2011) in the metaphors by teacher training applicants, except for the role of teacher as learner, which has not been explicitly mentioned by the participants.

Nikitina and Furuoka (2008), after reviewing studies that employed metaphors to approach the conception of teachers and teaching, observed that certain images (teachers as father/mother and teachers as artists) feature in diverse educational and sociocultural contexts. Likewise, MassenhillShaw and Mahlios (2008) found that upbringing was one of the prevailing categories, as did Lin, Shein and Yang (2012). A study carried out with students in their fifth and eighth year of elementary school determined that, among the students, the most recurrent metaphor for teacher was that of father/mother (Karadag and Gültekin, 2012). It does seem that students of teacher training reach university with an assumed and unrealized conception of the profession, derived from their own experience as students or from their own culture (Palencia Villa, 2009), which ties to an interesting aspect to consider during training: prestige and the social conception of teaching.

The link between the teaching profession and familiar figures, either fatherly or motherly, is more usual in first-year undergraduate students, which could mean that, throughout their training, in addition to the affective side of teaching, students become more aware of the importance of acquiring technical skills required for their satisfactory professional performance. On that account, some students connect teachers to fathers or mothers because of the emotional bond, because of their selflessness or because they are a source of support, whereas other students create that connection because they consider teachers to be co-responsible for children's education, and several others because teachers offer protection, like "a lion would to his cubs". Some students also underscore order, respect and discipline, showing an autocratic vision of teachers (Seferoglu, Korkmazgil and Ölcü, 2009).

The awareness of the professional nature of teachers, which develops throughout training, involves the idea that teachers, as part of the educational 
198 Martínez-de-la-Hidalga \& Villardón-Gallego-Using Teaching Metaphors

system, are agents of social construction and transformation, and are therefore of paramount importance. Social metaphors connected to this idea include technical professions such as "architect" or "engineer". These results concur with the research carried out by Vadeboncoeur and Torres (2003), in which students in training, at the end of their studies, emphasize the role of teachers as social agents.

Metaphors provide a glimpse into different conceptions of teaching. Focusing on the classification devised by Martínez, Sauleda and Huber (2001), the metaphors submitted by the pre-service teachers can be regrouped according to the underlying model of education:

\section{Behaviorist/transmissive}

According to "locus of control" category (Buchanan, 2015), this conception includes a view of learning as teacher-centered (Thomson, 2015). They define teachers as "bakers", "hammers" or "jewelers" who shape materials, which in turn represent students.

Teachers are again the center of the teaching process for students who consider them to be a source of knowledge, comparing them to "an encyclopedia" or "the Internet", placing a greater weight on the transmission of subject-related knowledge rather than on other types of learnings.

Additionally, this perspective also includes students who assume there is one single possible path through which all students must be guided: "train engine pulling the wagons" or "boat that follows the river to the sea".

The view of teachers as family members who protect, bring order and discipline and take on a "fatherly" role would also enter this perspective of teaching.

In this study, metaphors related to Family are much more prevalent in the first year than in the fourth year, and the number of first-year students submitting metaphors with teachers as being the Main Characters is also slightly larger than that of fourth-year students. There is no difference, however, in the percentage of students who consider teachers to be a source of knowledge.

In light of these results, it is safe to say that, throughout training, there is a decline in the transmissive conception of education, with teachers being the main characters and students only being passive agents in the process. 
This result, however, contrasts with the results obtained by Mellado, Bermejo and Mellado (2012), who found a prevalence of this behaviorist conception of education in future Secondary School teachers at the end of their training. The fact that Secondary School teachers training students have first completed their undergraduate learning in other disciplines may account for that difference.

\section{Cognitive/Constructivist}

In this conception of education, learners take on an active role and teachers are companions who support and help in the process.

The Support category features metaphors that consider teachers to be guides and resources, whose objective is to create autonomous people who can develop their whole potential, which in turn requires diversity to be taken into account. The Teaching category includes metaphors that consider teachers to be references (North star, lighthouse), role models who guide students in their integral development.

For example, metaphors such as "key that helps open different doors" or "branch on which to lean until we can fly" consider teachers to be a resource on which one can lean, or a guide that ushers students in their development towards autonomy, which can follow different paths, reflect a constructivist leaning, that of student-centered teaching, focusing on individuality (Thomson, 2015). The conception of teachers as guides has surfaced in diverse studies (Seferogly, Korkmazgil and Ölcü, 2009; Yesilbursa, 2012).

Furthermore, from this perspective, a key task of teachers is the full development of each student's potential. In this regard, teachers must be "gardeners" or "farmers", "carefully tending to the plants so that they grow and shine in all their glory". In the research carried out by Kalra and Baveja (2012), teacher training students also used metaphors such as "plants", "flowers", and "trees" to refer to learners.

Metaphors included in the Support category are far more abundant among last-year students than among first-year students, which indicates a shift throughout training, from a transmissive to a more constructivist conception of education. Namely, in this study, participants who have finished their training consider Support to be more important, along with Teaching, which, albeit commonly linked to the idea of teachers and 
200 Martínez-de-la-Hidalga \& Villardón-Gallego-Using Teaching Metaphors

considered to be an important task, features somewhat more prominently among first-year students.

In a study carried out by López-Luengo, Torrego-Egido and Vallés-Rapp (2015) with Early Childhood Education teachers, as found in this study, there are more metaphors with emotional content at the beginning of training, and, as training advances, there is a prevalence of metaphors linked to leading and guidance roles.

The differences in frequency in the answers for each category among students at the beginning of their training and students at the end of their training denote the shifts that happen throughout the training process in their conception of teaching and teachers. These results concur with the findings by Akar and Yildirin (2009) in their research on aspiring teachers: before the implementation of training based on constructivist learning environments, aspiring teachers chose metaphors related to leadership and control, adopting a disciplinarian position; however, after the exposure to such learning environments, they included messages of cooperation and sensitization towards individual differences. This evolution, from a transmissive conception of teaching to a more constructivist conception, has also been identified in other studies (Leavy, McSorley and Boté, 2007; Seung, Park and Narayan, 2011; Tannehill and MacPhail, 2012; Krull, Koni and Oras, 2013).

\section{Sociohistorical/Social Learning}

Some of the included metaphors, especially among last-year students, reflect the importance of context on professional performance. Strikingly, however, no metaphors have been found with clear references to social learning through interaction. This result must, without a doubt, spark reflection among teacher educators regarding the need to explicitly mention this element during teacher training. These results concur with those obtained by Krull, Koni and Oras (2013), who didn't find the conception of teaching to evolve towards a socioconstructivist outlook throughout initial teacher training. Sumsion (2003) suggests that the training curriculum itself could help perpetuate discourses and social conceptions regarding the figure of teachers. 
The model of education underlying superficial metaphors matches generative metaphors. Vadeboncoeur and Torres (2003), in their research with student teachers, identified two conceptions of teaching that can also be inferred from the results of this study: transmissive teaching and transformative teaching. The former defends an authoritarian role for teachers, who are responsible of improving students through their care and the transmission of knowledge. The latter, in turn, maintains that education must necessarily lead to the empowerment of people and the promotion of change in society. The first step in this transformative teaching is the creation of a suitable environment, which is protective and full of opportunities for students to actively build knowledge. Transmissive education coincides with the behavioral vision, whereas transformative education corresponds to the constructivist and social vision. As Vadeboncoeur and Torres found in their research, fourth-year undergraduate students submit more metaphors linked to the transformative conception with teachers as social agents- when compared to first-year students, which can be viewed as an effect of initial teacher training.

Some students, through their metaphors, highlight the importance of the figure of "teacher", either because education provides the foundation and fosters the development of people, or because of the aforementioned transformative power that can reshape society.

But in order to achieve an understanding of teaching in all its complexity, it is necessary to account for the context itself in which it is practiced. The profession also requires the development of many competences; so much so, that some students use fictional characters to represent teachers as "wizards" or "superheroes".

This complexity, along with the importance of the profession, leads directly to a clear need of teacher training that seeks to create excellent professionals, committed to their students and to society. And there can be no doubt that different conceptions of teaching entail different ways of practicing the profession, which is why it is important to become aware of our own conceptions, debate around them and reflect on them.

Consequently, it would be suitable to conclude that metaphors are an adequate tool to identify the diverse conceptions of teaching, and they are also a suitable resource to develop professional identity, if worked on deliberately (Kalra and Baveja, 2012; Tannehill and MacPhail, 2012), as a 
way of overcoming conceptions of teaching derived from previous experiences as learners. This must be a central learning objective during initial teacher training due to the great influence those conceptions have on professional identity (Mahlios, Massengill-Shaw and Barry, 2010).

From a socioconstructivist standpoint, language is a tool to promote preservice teachers' cognitive development. More specifically, metaphors incorporate sociocultural and cognitive actions (Vygotsky, 2002); therefore, as metaphors help build representations of oneself and of the profession (Kramsch, 2003), they can be used during initial training (Perry and Cooper, 2001; Woollard, 2005). In this regard, reflection and dialogue on superficial metaphors can have a transformative effect on the teaching-related conceptions of teacher training students (Vadeboncoeur and Torres, 2003) and can provide a medium to connect teaching practice with theory (Leavy, McSorley and Boté, 2007). In fact, many studies have shown that working on metaphors helps modify conceptions on the teaching profession and teaching itself (Buaraphan, 2011; Sykes, 2011; Kim, 2012; Simon, 2013; Tait-McCutcheon and Drake, 2016).

In this study, the comparison between the metaphors at the beginning of training and those from the end of training has been cross-sectional, and not longitudinal. That is to say, there has not been a follow-up on the evolution of the professional image of the same cohort, gathering information at two different times; instead, information was gathered from two different cohorts, which introduces certain uncontrolled variables. Nevertheless, this study has provided insight into the professional conceptions that students hold and the differences found in these conceptions at different times in their initial teacher training.

It would be of interest to carry out a longitudinal study on the evolution of teaching-related conceptions through metaphors, both during initial teacher training and during the years of professional practice. Additionally, an analysis of the elements that motivate said shift or influence such an evolution, either contextually or deliberately during teacher training programs, could provide additional insight that would be of use when designing future curricula.

Lastly, the evidence that students, throughout their initial teacher training, have not acquired conscience of the importance of social and 
situated learning, based on dialogue and interaction, should lead a reflection on the training program being implemented, in order to determine the reasons behind such results and devise proposals for improvement in this area, as evidence already exists on the potential of dialogue and interaction for learning and development (Soler, 2015). Furthermore, it could also be important to further the idea that teachers also learn through dialogue and interaction with their students.

\section{References}

Akan, D., Yalçin, S. \& Yildirim, I. (2013). Teachers' mental /metaphorical perceptions to Education Inspector. Mevlana International Journal of Education, 3 (19), 58-67.

Akar, H. \& Yildirim, A. (2009). Change in teacher candidates' metaphorical images about classroom management in a social constructivist learning environment. Teaching in Higher Education, 14 (4), 401-415. doi: 10.1080/13562510903050152

Boyd, P. (2014). Learning Teaching in School. In H. Cooper (ed.), Professional Studies in Primary Education (pp. 267-288). Los Angeles: Sage.

Buaraphan, K. (2011). Metaphorical Roots of Beliefs about Teaching and Learning Science and their Modifications in the Standard-Based Science Teacher Preparation Programme. International Journal of Science Education, 33 (11), 1571-1595. doi:

10.1080/09500693.2010.528462

Buchanan, J. (2015). Metaphors as Two-way Mirrors: Illuminating Preservice to In-service Teacher Identity Development. Australian Journal of Teacher Education, 40 (10), 33-50.

Emerson, L. \& Mansvelt, J. (2014). 'If they`re the customer, I'm the meat in the sandwich': an exploration of tertiary teachers ' metaphorical constructions of teaching. Higher Education Research and Development, 33 (3), 469-482. doi: 10.1080/07294360.2013.841653

Farrell, T. (2006). "The teacher is an octopus": Uncovering preservice English language teachers' prior beliefs through metaphor analysis. RELC, 37 (2), 236-248. doi: 10.1177/0033688206067430 
204 Martínez-de-la-Hidalga \& Villardón-Gallego-Using Teaching Metaphors

Glaser, B. \& Strauss, A. (1967). The discovery of Grounded Theory:

Strategies for qualitative Research. New York: Aldine Publising. Impedovo, M. A. (2016). In-service Teachers' Sense of Agency after Participation in a Research Master Course. International Journal of Educational Psychology, 5 (3), 281-307. doi:

10.17583/ijep.2016.2206

Kalra, M.B. \& Baveja, B. (2012). Teacher thinking about knowledge, learning and learners: A metaphor analysis. Procedia - Social Behavioral Sciences, 55, 317-326. doi: 10.1016/j.sbspro.2012.09.509

Karadag, R. \& Gültekin, M. (2012). The Metaphors That Elementary School

Students use to Describe the Term "Teacher". Mersin University Journal of the Faculty of Education, 8 (1), 69-83.

Kasoutas M. \& Malamitsa K. (2009). Exploring Greek Teachers' Beliefs Using Metaphors. Australian Journal of Teacher Education, 34 (2), 64-83. doi: 10.14221/ajte.2009v34n2.6

Kim, M. S. (2012). Cultural-historical activity theory perspectives on constructing, ICT-mediated metaphors of teaching and learning. European Journal of Teacher Education, 35 (4), 435-448. doi:10.1080/02619768.2011.643393

Konakli, T. \& Gogus, N. (2013). Metaphorical Perceptions of pre-service teachers in related to faculty of education: Asample of Kokaeli University Faculty of Education. International Journal of Human Sciences, 10 (2), 67-93.

Kramsch, C. (2003). "Metaphor and the subjective construction of beliefs". In P. Kalaja \& A.M.F. Barcelos (eds.), Beliefs about SLA (pp. 109128). Netherlands: Springer.

Krull, E., Koni, I. \& Oras, K. (2013). Impact on student teachers' conception of learning and teaching from studying a course in educational psychology. Asia-Pacific Journal of Teacher Education, 41 (2), 218231. doi: 10.1080/1359866X.2013.777026

Lakoff, G. \& Johnson, M. (1980). Metaphors We Live By, Chicago: University of Chicago Press.

Landau, M. J., Meier, B. P., y Keefer, L. A. (2010). A metaphor-enriched social cognition. Psychological bulletin, 136 (6), 1045-1067. doi: 1045-1067. 10.1037/a0020970 
Leavy, A.M., McSorley, F.A. \& Boté, L.A. (2007). An examination of what metaphor construction reveals about the evolution of preservice teachers' beliefs about teaching and learning. Teaching and Teacher Education, 23, 1217-1233. doi: 10.1016/j.tate.2006.07.016

Lopez-Luengo, M. A., Torrego-Egido, L. M., \& Vallés-Rapp, C. (2015). ¿Qué Metáforas Personales Definen al Profesorado de Educación Infantil en Formación? REICE. Revista Iberoamericana sobre Calidad, Eficacia y Cambio en Educación, 13 (3), 37-56.

Lin, W., Shein, P. P. \& Yang, S. C. (2012). Exploring personal EFL teaching metaphors in pre-service teacher education. English Teaching: Practice and Critique, 11 (1), 183-199.

Mahlios, M., Massengill-Shaw, D. \& Barry, A. (2010). Making sense of teaching through metaphors: a review across three studies. Teachers and Teaching: theory and practice, 16 (1), 49-71. doi:

10.1080/13540600903475645

Massenhill-Shaw, D. \& Mahlios, M. (2008). Pre-service teachers' metaphors of teaching and literacy. Reading Psychology, 29 (3), 31-60. doi: 10.1080/02702710701568397

Martinez, M.A., Sauleda, N. \& Huber, G.L. (2001). Metaphors as blueprints of thinking about teaching and learning. Teaching and Teacher Education, 17 (8), 965-977.

McGrath, I. (2006). Teachers' and learners' images for coursebooks. ELT Journal, 60 (2), 171-80.

Mellado, L., Bermejo, M. L. \& Mellado, V. (2012). Personal metaphors of prospective secondary economics and science teachers. Asia-Pacific Journal of Teacher Education, 40 (4), 395-408. doi:

10.1080/1359866X.2012.724658

Nikitina, L. \& Furuoka, F. (2008). Measuring Metaphors: A Factor Analysis of Students' Conceptions of Language Teachers Metaphor, Metaphoric.de, 15, 161-180.

Palencia Villa, M. (2009). Transformaciones del modelo cultural de las educadoras de Preescolar. Revista mexicana de investigación educativa, 14 (42), 787-811.

Perry, C. \& Cooper, M. (2001). Metaphors are good mirrors: reflecting on change for teacher educators. Reflective practice, 2 (1), 41-52. doi: 10.1080/14623940120035514 
206 Martínez-de-la-Hidalga \& Villardón-Gallego-Using Teaching Metaphors

Pinegar, S., Mangelson, J., Reed, M. \& Groves, S. (2011). Exploring preservice teacher' metaphors plotlines. Teaching and Teacher Education, 27, 639-647.

Saban, A., Kocbeker, B. N. \& Saban, A. (2006). An Investigation of the Concept of Teacher Among Prospective Teachers through Metaphor Analysis. Educational Science: Theory y Practice, 6 (2), 509-522. Seferoglu, G., Korkmazgil, S. \& Ölcü, Z. (2009). Gaining insights into teachers' ways of thinking via metaphors. Educational Studies, 35 (3), 323-335.

Seung E., Park, S. \& Narayan, R. (2011). Exploring Elementary Pre-service Teachers` Beliefs about Science Teaching and Learning as Revealed in Their Metaphor Writing. Journal of Science Education and Technology 20 (6), 703-714. doi: 10.1007/s10956-010-9263-2

Sexton, D. M. (2008). Student Teacher Negotiating Identity, Role, and Agency. Teacher Education Quarterly, 35 (3), 73-87.

Sfard, A. (1998). On two metaphors of learning and the dangers of choosing just one. Educational Researcher, 27 (2), 4-13.

doi: 10.3102/0013189X027002004

Simon, S. (2013). The Weaving of a Tapestry: a Metaphor for Teacher Education Curriculum Development. Australian Journal of Teacher Education, 38, (8), 73-91. doi: 10.14221/ajte.2013v38n8.5

Soler, M. (2015). Biographies of "Invisible" People Who Transform Their Lives and Enhance Social Transformations Through Dialogic Gatherings. Qualitative Inquiry, 21 (10), 839-947.

Sumsion, J. (2003). Rereading Metaphors as Cultural Texts: A Case Study of Early Childhood Teacher Attrition. The Australian Educational Researcher, 30 (3), 67-87. doi: 10.1080/09518390903443282

Sykes, J. D. (2011). Facilitating reflection on implicit learner beliefs through metaphor elicitation. Journal of Pan-Pacific Association of Applied Linguistics, 15 (1), 91-113.

Tait-McCutcheon S. \& Drake, M. (2016). If the jacket fits: A metaphor for teacher professional learning and development. Teaching and Teacher Education, 55, 1-12. doi: 10.1016/j.tate.2015.12.0050742-051X/

Tannehill, D. \& MacPhail, A. (2012). What examining teaching metaphors tells us about pre-service teachers' developing beliefs about teaching 
and learning. Physical Education and Sport Pedagogy, 19 (2), 149163. doi:10.1080/17408989.2012.732056

Thomson, M.M. (2015). Metaphorical images of schooling: beliefs about teaching and learning among prospective teachers from the United States displaying different motivational profiles, Educational Psychology: An International Journal of Experimental Educational Psychology, 36 (3), 502-525. doi: 10.1080/01443410.2015.1024612

Trinidad, A., Carrero, V. \& Soriano, R. (2006). Teoría fundamentada $<$ Grounded theory>. La construcción de la teoría a través del análisis interpretacional. Madrid: CIS (Centro de Investigaciones Sociológicas).

Vadeboncoeur, J. A. \& Torres, M. N. (2003). Constructing and Reconstructing Teaching Roles: a focus on generative metaphors and dichotomies. Discourse: studies in the cultural politics of education, 24 (1), 87-103. doi: 10.1080/0159630032000069402

Vygotsky, L. 2002. Thought and language. Cambridge: MIT Press.

Wegner, E. \& Nückles, M. (2015). Training the brain or tending a garden?

Students' metaphors of learning predict self-reported learning patterns. Frontline Learning Research, 4, 95-109. doi:

10.14786/flr.v3i4.212

Woollard, J. (2005). The implications of the Pedagogic Metaphor for Teacher Education in Computing. Technology, Pedagogy and Education, 14 (2), 189-204.

Yesilbursa, A. (2012). Using metaphor to explore the professional role identities of higher education English language instructors. Procedia Social and Behavioral Sciences, 46, 468-472. doi:

10.1016/j.sbspro.2012.05.143. 
208 Martínez-de-la-Hidalga \& Villardón-Gallego-Using Teaching Metaphors

Zoe Martínez de-la-Hidalga is a Professor in the Faculty of Psychology and Education at University of Deusto.

Lourdes Villardón-Gallego is a Professor in the Faculty of Psychology and Education at University of Deusto.

Contact Address: Faculty of Psychology and Education, University of Deusto.48014 Bilbo, Bizkaia. Email: zoe@ deusto.es 